\title{
Comparative Efficacy of Nebulized $7 \%$ Hypertonic Saline versus $0.9 \%$ Normal Saline with Salbutamol in Children with Acute Bronchiolitis
}

\author{
MD. SAIFUL ISLAM ${ }^{1}$, MD. ABID HOSSAIN MOLLAH ${ }^{2}$, ROKEYA KHANAM ${ }^{3}$, ABU SAYEED CHOWDHURY ${ }^{4}$, \\ MD. MAHFUZUR RAHMAN ${ }^{5}$, SHAH ABDULLAH-AL BAQUI ${ }^{6}$, MUHAMMED ANISUR RASHID ${ }^{7}$
}

\begin{abstract}
s
Background: Acute bronchiolitis is an acute viral lower respiratory tract infection of infants and is the leading cause of hospitalization of infants below 2 years of age. Being a viral disease, there is no effective treatment of this problem other than supportive care. To provide this care, both $0.9 \%$ normal saline with salbutamol and $3 \%$ hypertonic saline has been found effective. This study was undertaken to assess the efficacy of 7\% hypertonic saline on recovery from acute bronchiolitis.
\end{abstract}

Methodology: This was a randomized controlled trial, carried out in the Department of Paediatrics, Dhaka Medical College Hospital (DMCH), Bangladesh between January 2015 to December 2015. A total of 90 children from 1 month to 2 years of age of either sex who were diagnosed and admitted as acute bronchiolitis were enrolled. After enrollment, they were randomly assigned to either $7 \%$ nebulized hypertonic saline (Group-I $=45$ ) or to $0.9 \%$ nebulized normal saline with salbutamol (Group-II $=45$ ). The efficacy was determined by assessing clinical severity score and length of hospital stay. Data were analyzed using computer software SPSS version 19.

Result: In this study the two groups were almost similar with respect to their demographic and baseline clinical severity score. After intervention the clinical severity score of both treatment modalities were reduced (Group-I(HS) were 7.9, 6.8, 3.8, 1.4, 1.33 while in Group-II(NS+ Salbutamol) score were 8.6, 7.6, 4.9, 3.11, 2.12) but the reduction was significant more in children who received $7 \%$ nebulized hypertonic saline than those who received $0.9 \%$ nebulized normal saline with salbutamol. Majority $42(93.3 \%)$ of group-I(HS) children recovered at the end of 72 hours whereas $17(37.8 \%)$ of the children of group-II (NS+ Salbutamol) recovered from the disease during the same period. Length of hospital stay was shorter in hypertonic saline group compared to normal saline with salbutamol group $(56.36 \pm 12.33$ hours vs71.07 \pm 13.48 hours, $p<.001)$. The patients of hypertonic saline group required a shorter duration of oxygen therapy compared to normal saline with salbutamol group (12.53 \pm 3.58$)$ hours vs $(20.25 \pm 4.15)$ hours, $(p=0.009)$.

Conclusion: $7 \%$ hypertonic saline was found more effective than $0.9 \%$ normal saline with salbutamol in terms of reducing clinical severity, length of hospital stays and duration of oxygen therapy.

Keywords: Acute Bronchiolitis, 7\% Hypertonic saline

1. Junior Consultant, Department of Paediatrics, Dhaka Medical College Hospital.

2. Professor and Head, Department of Paediatrics, Ibrahim Medical College. Dhaka

3. Professor of Paediatrics, Dhaka Medical College.

4. Junior Consultant, Department of Paediatrics. Mugda Medical College Hospital, Dhaka.

5. SMO, Department of Paediatrics, National Medical College Hospital, Dhaka.

6. Junior Consultant of Paediatrics, 250 Bed Gopalganj General Hospital, Gopalganj.

7. Junior Consultant of Paediatrics, Upazilla Health Complex, Hathazari, Chattogram

Correspondence: Dr. Md. Saiful Islam. Junior Consultant, Department of Paediatrics, Dhaka Medical College Hospital Mob: +8801715024950, Email: dr.saif_53@yahoo.com

Received: $21-04-2018$

Accepted: 24-06-2019

\section{Introduction}

Acute bronchiolitis is the commonest viral lower respiratory tract infection of under 2 years children and their treatment is virtually supportive. ${ }^{1,2}$ like oxygen supplementation, ensuring adequate hydration and nutrition. ${ }^{3}$ Anti-cholinergic drugs e.g. ipratropium bromide and normal saline with salbutamol nebulization are variable. ${ }^{4,5}$ Antiviral agents available but expensive and role is controversial. Antibiotic has no role. ${ }^{6}$ However, there are evidence hypertonic saline solution are effective and improve the cases through mucociliary clearance and by reducing airway edema. ${ }^{7}$ Study shows, the 
improvement in the clinical severity scores was significant, those was treated with hypertonic saline. $8,9,10$ To our knowledge, $7 \%$ hypertonic saline has not been previously investigated in our country. So, we hypothesized that simply $7 \%$ hypertonic saline in the nebulization without salbutamol to these babies may improve clinical severity scores and decrease the length of hospitalization.

\section{Materials and methods}

The study was a randomized controlled trial conducted in the department of Paediatrics, Dhaka Medical College Hospital (DMCH) from January 2015 to December 2015. Informed consent was obtained from a parent or legal guardian of each patient enrolled in the study. Children aged between one month to two years presenting with preceding or existing runny nose, cough, breathing difficulty, chest indrawing and whose chest $x$-ray showed hyperinflation, hypertranslucency without any cardiac problem and admitted during the study period was enrolled consecutively as study population. Exclusion criteria were previous history of wheezing, any use of bronchodilators within 2 hours of presentation, chronic cardiac or respiratory disease or respiratory failure or requiring mechanical ventilation, inhaling the nebulized any hypertonic saline within 12 hours of intervention.

After inclusion and exclusion this study included 90 patients with acute bronchiolitis. The two groups were randomly assigned to $7 \%$ hypertonic saline nebulization $(n=45)$ and $0.9 \%$ normal saline with salbutamol nebulization $(n=45)$ by lottery method. Relevant history and physical findings were recorded in a pre-tested, semi-structured questionnaire. Variables like clinical severity score assessed by using respiratory distress assessment instrument described by Wang et al ${ }^{11}$

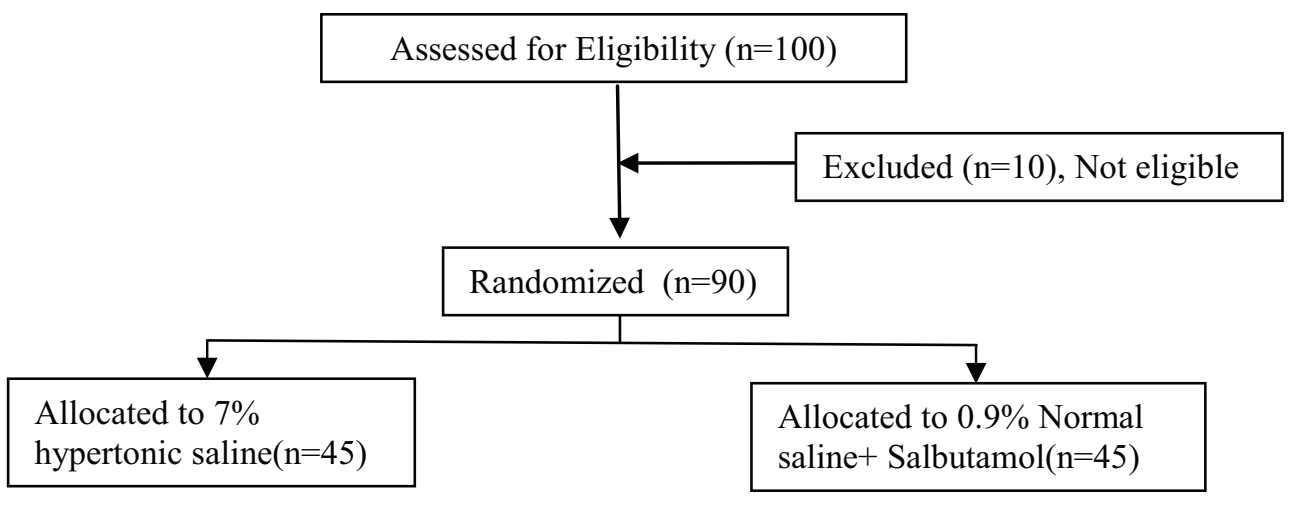

Fig: Flowchart

Table I

Respiratory distress Assessment Instrument

\begin{tabular}{|c|c|c|c|c|c|}
\hline Variables & 0 & 1 & 2 & 3 & total \\
\hline $\begin{array}{l}\text { Respiratory } \\
\text { rate }\end{array}$ & $\begin{array}{l}<30 \\
\text { breaths/min }\end{array}$ & $\begin{array}{c}31 \text { to } 45 \\
\text { Breaths/min }\end{array}$ & $\begin{array}{c}46 \text { to } 60 \\
\text { Breaths/min }\end{array}$ & $\begin{array}{l}\quad>60 \\
\text { breaths/min }\end{array}$ & 3 \\
\hline Wheezing & none & $\begin{array}{l}\text { Terminal expiratory } \\
\text { or only with } \\
\text { stethoscope }\end{array}$ & $\begin{array}{l}\text { Entire expiration } \\
\text { or Audible on } \\
\text { Expiration without } \\
\text { stethoscope }\end{array}$ & $\begin{array}{l}\text { Inspiration and } \\
\text { expiration without } \\
\text { stethoscope }\end{array}$ & 3 \\
\hline Retraction & none & $\begin{array}{l}\text { Intercostals } \\
\text { only }\end{array}$ & Tracheosternal & $\begin{array}{l}\text { Severe with } \\
\text { nasal flaring. }\end{array}$ & 3 \\
\hline $\begin{array}{l}\text { General } \\
\text { condition }\end{array}$ & normal & & & $\begin{array}{l}\text { Irritable, lethargic, } \\
\text { or poor feeding }\end{array}$ & 3 \\
\hline
\end{tabular}


Oxygen saturation was measured by using noninvasive pulse oxymeter and recorded on admission as baseline characteristics. A child with oxygen saturation value $<90 \%$ was designated as having significant hypoxia ${ }^{6}$ After taking written informed consent drug was given according to dose schedule. Group-I received nebulization with $3 \mathrm{ml}$ of $7 \%$ hypertonic saline and group-II received nebulization with $3 \mathrm{ml}$ of $0.9 \%$ normal saline with $0.3 \mathrm{ml}$ salbutamol three times every day at intervals of 8 hours until they were improved enough for discharged. Each of the two groups received the same supportive measures like propped up positioning, o-p, nasal suction when needed, iv fluid, feeding, oxygen therapy (when oxygen saturation $<90 \%$ ), paracetamol for fever, antibiotic and counseling. Cases were monitored by respiratory distress assessment instrument (RDAl) score at 12 hourlies initially then 24 hourly till the patient was ready for discharge. The time required from the initiation to the withdrawal of oxygen therapy was recorded. Oxygen therapy was stopped when the patients maintaining $\mathrm{SP}_{02}>95 \%$. Length of hospital stay from admission to time taken to discharged was measured. The decision to discharge the patients was made in the morning rounds by the attending physician, based on clinical grounds alone. The outcome variables were (1) clinical severity score (2) length of hospital stay (3) oxygen saturation in room air (4) duration of oxygen supplementation (5) Side effects of drugs. Collected data were processed and analyzed using computer software SPSS (Statistical Package for Social Sciences), version 19. The test statistics used to analyze the data presented on categorical scale were Chi-square and Unpaired t-Test (for comparison of data between groups). Level of significance was set $5 \%$ and $p$-value $<0.05$ was considered significant.

Table II

Demographic characteristics between groups

\begin{tabular}{lccc}
\hline \multirow{2}{*}{$\begin{array}{l}\text { Demographic } \\
\text { characteristics }\end{array}$} & $\begin{array}{c}\text { Group-I) } \\
(H S \\
(n=45)\end{array}$ & $\begin{array}{c}\text { Group-II } \\
(\text { NS }+ \\
\text { Salbutamol }) \\
(n=45)\end{array}$ & $\begin{array}{c}p \text { value } \\
\text { Age }\end{array}$ \\
\hline 6 & $22(48.9)$ & $33(73.3)$ & \\
$6-12$ & $15(33.3)$ & $7(15.6)$ & \\
$>12$ & $8(17.8)$ & $5(11.1)$ & \\
Mean \pm SD\# & $7.81 \pm 5.32$ & $5.81 \pm 4.62$ & 0.06 \\
Sex * & & & \\
Male & $31(68.9)$ & $31(68.9)$ & 1.0 \\
Female & $14(31.1)$ & $14(31.1)$ & \\
\hline
\end{tabular}

Table III

Clinical presentation of the cases on admission

\begin{tabular}{cc}
\multicolumn{2}{c}{ Group } \\
\hline $\begin{array}{cc}\text { Group -I(HS) } & \text { Group-II } \\
(n=45), & (N S+ \\
\text { No. }(\%) & \text { Salbutamol) } \\
& (n=45), \text { No. }(\%)\end{array}$
\end{tabular}

\begin{tabular}{lcc}
\hline Clinical presentation & & \\
Breathing difficulty & $45(100)$ & $45(100)$ \\
Cough & $45(100)$ & $45(100)$ \\
Fever & $25(55.6)$ & $24(53.3)$ \\
Runny nose & $45(100)$ & $45(100)$ \\
Wheeze & $45(100)$ & $45(100)$ \\
Rhonchi & $45(100)$ & $45(100)$ \\
Chest indrawing & $45(100)$ & $45(100)$ \\
Tachypnoea & $38(84.4)$ & $41(91.1)$ \\
Tachycardia & $35(77.7)$ & $38(84.4)$ \\
Head nodding & $2(4.4)$ & $3(6.7)$ \\
Nasal flaring & $2(4.4)$ & $3(6.7)$ \\
Feeding difficulty & $24(53.3)$ & $22(48.9)$ \\
Oxygen saturation & $95.04 \pm 0.93$ & $94.78 \pm 0.88$ \\
(mean $\pm S D$ ) \# & & \\
Radiological finding & & \\
Increased translucency & $41(91.11 \%)$ & $43(95.5)$ \\
Hyperinflation & $37(82.2 \%)$ & $41(91.11 \%)$ \\
Low flat diaphragm & $39(86.66)$ & $43(95.5)$ \\
\hline
\end{tabular}

Table IV

Mean clinical severity score

\begin{tabular}{lccc}
\hline Mean clinical & $\begin{array}{c}\text { Group-I } \\
(\mathrm{HS}) \\
\text { severity score }\end{array}$ & $\begin{array}{c}\text { Group-II } \\
(\mathrm{NS}+45)\end{array}$ & $\begin{array}{c}\mathrm{p}- \\
\text { value } \\
\text { Salbutamol }) \\
(\mathrm{n}=45)\end{array}$ \\
\hline At baseline & 7.9 & 8.6 & .061 \\
At 12 hours & 6.8 & 7.6 & .074 \\
At 24 hours & 3.8 & 4.9 & $.041^{*}$ \\
At 48 hours & 1.4 & 3.1 & $.012^{*}$ \\
At 72 hours & 1.3 & 2.1 & .081 \\
\hline
\end{tabular}


Table V

Comparison of duration of oxygen therapy between groups

\begin{tabular}{lccc}
\hline \multirow{2}{*}{$\begin{array}{l}\text { Duration of } \\
\text { oxygen therapy } \\
\text { (hours) }\end{array}$} & $\begin{array}{c}\text { Group- I } \\
(\mathrm{HS}) \\
(\mathrm{n}=5)\end{array}$ & $\begin{array}{c}\text { Group-II } \\
(\mathrm{NS}+\end{array}$ & $\begin{array}{c}\text { G- } \\
\text { value } \\
\text { Salbutamol) } \\
(\mathrm{n}=6)\end{array}$ \\
\hline Mean \pm SD & $12.53 \pm 3.58$ & $20.25 \pm 4.15$ & $0.009^{*}$ \\
\hline
\end{tabular}

Table VI

Comparison of recovery and discharge from hospital between groups

\begin{tabular}{lccc}
\hline $\begin{array}{l}\text { Recovery } \\
\text { and } \\
\text { discharge }\end{array}$ & $\begin{array}{c}\text { Group-I } \\
\text { I(HS) } \\
(\mathrm{n}=45)\end{array}$ & $\begin{array}{c}\text { Group -II } \\
(\mathrm{NS}+ \\
\text { Salbutamol }) \\
(\mathrm{n}=45)\end{array}$ \\
\hline $\begin{array}{l}\text { Rapid (within } \\
72 \text { hours) }\end{array}$ & $42(93.3 \%)$ & $17(37.8 \%)<0.001^{*}$ \\
$\begin{array}{l}\text { Gradual (after } \\
72 \text { hours) }\end{array}$ & $3(6.7 \%)$ & $28(62.2 \%)$ \\
\hline
\end{tabular}

Table VII

Comparison of Length of hospital stays between groups

\begin{tabular}{|c|c|c|c|}
\hline \multirow[b]{2}{*}{$\begin{array}{l}\text { Length of } \\
\text { hospital } \\
\text { stay } \\
\text { (hours) }\end{array}$} & \multicolumn{2}{|c|}{ Group } & \multirow{2}{*}{$\begin{array}{c}\mathrm{p}- \\
\text { value }\end{array}$} \\
\hline & $\begin{array}{c}\text { Group- I } \\
\text { (HS) } \\
(n=45)\end{array}$ & $\begin{array}{c}\text { Group- II } \\
(\text { NS }+ \\
\text { Salbutamol) } \\
(n=45)\end{array}$ & \\
\hline & $\begin{array}{c}56.36 \pm \\
12.33\end{array}$ & $\begin{array}{c}71.07 \pm \\
13.48\end{array}$ & $<0.001^{*}$ \\
\hline
\end{tabular}

\section{Discussion}

Bronchiolitis is a major public health problem throughout the world exerting significant morbidity and mortality This study demonstrated that clinical severity score of both the treatment groups were reduced but the reduction was much earlier in children who received $7 \%$ nebulized hypertonic saline than those who received $0.9 \%$ nebulized normal saline with salbutamol. Majority of the $7 \%$ hypertonic saline group children recovered within 72 hours, where as one third of the children of $0.9 \%$ normal saline with salbutamol group recovered from the disease during the same period. No side effect observed in either group. Similar observation were seen in another study, mean duration of hospital stay was shorter in hypertonic saline group. ${ }^{12}$ Another study demonstrated no additional clinical benefit from inhaled $7 \%$ hypertonic saline with epinephrine when compared with $0.9 \%$ normal saline with epinephrine. ${ }^{13}$ In this study mean time of $\mathrm{O} 2$ requirements in $7 \%$ hypertonic saline group 12.0 hours and 20 hours in $0.9 \%$ normal saline with salbutamol group $(p<0.009)$. Many of them used acute bronchiolitis severity score to evaluate patients over time and they found that inhaled $3 \%$ hypertonic saline with epinephrine administered by nebulization every 6-8 hours improved clinical severity score and reduced the length of hospital stay in hospitalized patients when compared with $0.9 \%$ saline with epinephrine. ${ }^{9}$ None of the studies reported any sideeffects. These findings go in favour of the findings of this study. Hypertonic saline decreases airway oedema, enhances mucociliary clearance by improving mucus flow, and thus decreases airway obstruction. ${ }^{14}$ From the above discussion, it seems that the use of nebulized $7 \%$ hypertonic saline in children admitted with acute bronchiolitis is a safe and effective therapy, although the optimum dose is unknown. Early, pre hospital intervention for bronchiolitis with this safe, effective, and inexpensive agent might save lives, reduce complications and hospitalizations, and be applicable for its wider use, including small communities where hospital care is not available.

\section{Conclusion}

$7 \%$ hypertonic saline was found more effective than $0.9 \%$ normal saline with salbutamol in terms of reducing clinical severity, length of hospital stays and duration of oxygen therapy. No side effect was observed in either group.

\section{References}

1. Canny DJ. Acute Bronchiolitis- Recent Advances in Treatment. Indian J Pediatr 1996; 63:45-51.

2. Smyth RL, Openshaw PJM. Bronchiolitis. Lancet 2006; 368:312-22.

3. Kabir ARM, Haq N, Amir R, Hossain A, Khatoon $S$, Shahin A et al. Evaluation of hospitalized infant and young children with bronchiolitis- a multicenter study. Maymensingh Med J 2003 Jul; 12(2):128-133. 
4. Bertrand P, Aranibar H, Castro E, Sanchez I. Efficacy of nebulized epinephrine vs salbutamol in hospitalized infants with bronchiolitis. PediatrPulmonol 2001; 31:284-288.

5. Hassan R, Hossain A, Mahmud AM, Kabir ARML, Amin RM, Rahman MM, et al. National guidelines: asthma, bronchiolitis, COPD. Bangladesh: Asthma Association, 2005.

6. Kabir AR, Mollah AH, Anwar KS, Rahman AK, Amin $\mathrm{R}$ and Rahman ME. Management of Bronchiolitis without antibiotics: a multicentre randomized control trial in Bangladesh, ActaPaediatrica 2009; 98(10):1593-1599.

7. Wark P, McDonald V, Jones A. Nebulised hypertonic saline for cystic fibrosis. Cochrane Database SystRev2005;(3):CD001506.

8. Daviskas E, Anderson SD. Hyperosmolar agents and mucociliary clearance in the diseased airway. J Aerosol Med 2006;19(1): 100 -109 .

9. Mandelberg A, Tal G, Witzling M. Someck E, Houri S, Balin A. et al. Nebulized 3\% hypertonic saline solution treatment in hospitalized infants with viral bronchiolitis. Chest 2003;123:481-7
10. Tal G, Cesar K, Oron A, Houri S, Ballin A, Mandelberg A. Hypertonic saline/epinephrine treatment in hospitalized infants with viral bronchiolitis reduces hospitalization stay: 2-year experience. Isr Med Assoc J 2006; 8(3) 169- 173.

11. Wang EEL, Milner RA, Navas L, Maj H. Observer agreement for respiratory signs and oximetry in infants hospitalized with lower respiratory infections. Am Rev Respir Dis 1992; 145:106-9

12. Khalid AA, Sakran M, Bruce L, Davidson B, Sayyed RE, Mahjoub H, et al. Nebulized $5 \%$ or $3 \%$ hypertonic or $0.9 \%$ saline for treating acute bronchiolitis in infant. J Padiatr. 2010; 157 : 630-4.

13. Jacobs JD, Foster M, Wan J, Pershad J. $7 \%$ hypertonic saline in acute bronchiolitis: a randomized controlled trial. Pediatrics. 2014;13

14. Mandelberg A, Amirav I. Hypertonic saline or high-volume normal saline for viral bronchiolitis: mechanisms and rationale. PediatrPulmonol 2010; 45: 36-40. 